O. Vasylchenko ${ }^{1}$, orcid.org/0000-0002-4464-3708, O. Lotiuk ${ }^{1}$, orcid.org/0000-0001-7119-754X,

A. Yevstihnieiev ${ }^{1}$, orcid.org/0000-0001-6994-1069,

A. Basalaieva ${ }^{2}$, orcid.org/0000-0001-7558-2621, S. Kustova ${ }^{3}$, orcid.org/0000-0003-3563-1454
1 - Taras Shevchenko National University of Kyiv, Kyiv, Ukraine, e-mail: rudenkosrg@gmail.com

2 - National Aviation University, Kyiv, Ukraine

3 - "Katerynchuk, Moor and Partners" Law Firm, Kyiv, Ukraine

\title{
THE ENVIRONMENTAL REGULATION OF MINING: LEGAL FOUNDATIONS
}

Purpose. To enhance the quality of Ukrainian legislation by improving the legal framework of public administration in the field of environmental regulation of mining in Ukraine.

Methodology. The authors used comparative and legal, historical, systemic, structural and functional, formal and logical, and dialectical research methods. The need to use an integrated research method is emphasized.

Findings. The authors investigated two problems actualized by the so-called "Adani Syndrome":

1. The criteria for assessing the impact on the environment and their legal force.

2. The legal framework governing the rights of the owner, the state and the public.

The above problems were studied in comparison with the legal support of environmental regulation of mining in Ukraine.

Originality. The experience of environmental regulation of mining in Australia is analyzed on the example of the conflict over the Carmichael mine project, resulting in disclosing the current state of Ukrainian legislation in this area. The directions of improving the legal foundations of public administration in the field of environmental regulation of mining in Ukraine have been brought up for discussion.

Practical value. The use of the obtained results will make it possible to eliminate the difference between the legal support of environmental regulation of mining in developed and developing countries. The proposals have been formulated to improve the legal regulation in the area under study in terms of detailing the powers of individual governing bodies of special competence, as well as in terms of procedures for assessing the environmental impact. The formulated proposals can help to strengthen the effectiveness of the legislation in power.

Keywords: public participation, environmental regulation, mining, Adani Syndrome, environmental consciousness

Introduction. Environmental regulation is based on international standards and international criteria that determine the vector of national legislation development. However, as practice shows, the international legal framework, on which the environmental regulation of mining is based, often conflicts with international politics, as well as social, political, economic and philosophical ideas promoted at the national level.

The authors of the article study the so-called "Adani Syndrome" and its legal consequences for Ukraine.

Results. The article "Public participation and the Adani Syndrome" [1] focuses on two main issues that stimulate rethinking of the legal framework for environmental regulation of mining.

The first problem is related to the framework on which the meanings combined in the phrase "public participation" are developed and regulated. Over the last thirty years, public participation has been viewed as a vital part of solving environmental problems and ensuring sustainable development of society [2]. Public participation has become a central principle in the development of state policy of the rule of law [3]. This is one of the foundations on which democracy as a political system is developed. All modern constitutions and basic laws contain and proclaim the concept and the principle of popular sovereignty. This means that the people are the supreme source of state power. The concept of popular sovereignty asserts that in a society organized for political action, the will of the people is the only correct standard for political action. Therefore, public participation is seen as an important element of the system of checks and balances in the rule of law. The people have an unconditional right to take direct part in the process of state policy and lawmaking [4].

(C) Vasylchenko O., Lotiuk O., Yevstihnieiev A., Basalaieva A., Kustova S., 2021
Public participation is seen as the main tool for informing the legislative, executive and judicial branches of planning, organization or financial activities [5]. Public participation is being promoted as a new paradigm expanding and refining the "people first" paradigm. It was called the concept of "more heads are better than one". The concept affirms public participation as an important force supporting productive and sustainable changes in society $[3,5]$.

Public participation such as public involvement in projects at the global, national and regional levels [6] is promoted by the similarly named international public organization, which has its branches in many countries of the world [7]. The most influential offices of the organization are located in the USA, Great Britain and Canada. "Public Participation" coordinates and promotes the influence of civil society in all branches of government. The strategic plan for the US branch of the organization for the period 2018-2020 reveals the vision of the role of public participation in the US public policy. "We envision a country where public participation is deeply embedded and widely applied, and where equitable, efficient, and informed decision-making processes improve the quality of our democracy" [7].

"Public Participation" promotes The Code of Ethics, which determines the Role of Practitioner for public participation. The mission of public participation is to increase the influence of the organization on decision-making at all government levels, as well as to increase the influence of its representatives, practitioners, who convey all concerns and suggestions to the public, government and political decision makers [7].

The second issue raised in the article "Public participation and the Adani Syndrome" [1] is related to the situation around the mine in Queensland's Galilee Basin, Australia, owned by the Indian multinational conglomerate Adani Group [8].

The project known as the Carmichael mine was submitted to the Australian government for approval in 2009. Initially, 
the project presented the Carmichael mine as the largest coal mine in the world, providing coal to India and Asia. The project envisaged creating of 10000 jobs [8]. The struggle that unfolded around the project and lasted for more than 10 years reveals the vector of development of the legal framework for environmental regulation of mining. It reveals the legal capabilities of each of the three stakeholders.

Consider the stakeholders in the environmental regulation of mining using the example of the conflict surrounding the Carmichael mine project. They are typical of developed and developing countries [9].

According to V.R. Nalule, mining industry is noticeable for a variety of social, economic and environmental impacts. From an economic point of view, mining contributes to government revenues and provides jobs for a significant number of people. On the other hand, mining has some social negative impacts, including violence, child labor, escalating gender inequality, health, and environmental impacts including deforestation and pollution [10]. The mining industry is harmful to health, and not only for workers directly involved in production. The harm is done to the population living in the region where mining activities are carried out [11]. That is why any projects related to the mining industry cause acute social and political conflicts in developed countries.

The first stakeholder in promoting the Carmichael mine was the Adani Group, the mine owner. D. Bezzubov and O. Pravotorova studied the place and role of multinational corporations in the world market of services and technologies. They highlighted the positive and negative consequences of the impact of the world economy globalization [12]. The positive consequences of the influence of multinational corporations are the promotion of high technologies that contribute to the economic growth of the region and the social sphere. A negative trend is the practice of multinational companies in influencing the economic and legal sphere of the countries of their presence and violating the fundamental rights of citizens of these states [12].

The second stakeholders in the Carmichael mine project were the Australian federal government and the Queensland state government, where the Carmichael mine was located. The Federal and Queensland state governments supported the project. The support of the project by Australian government and political authorities of Australia was based on economic, political and social benefits in the short and long term.

The third party to the conflict over the Carmichael mine was environmental NGOs, which were merged into the "public participation" branch. The third party opposed the Adani Group. Its reasoning was based on the following [8]:

1. The need to abandon coal as a source of energy. In accordance with the Paris Climate Agreement, Australia has pledged to cut emissions by $26 \%$ by 2030 when compared to the level of 2005 .

2. Adani Group project implementation paved the way for the approval of six other mines in the region.

3. Mine development in Queensland's Galilee Basin will disrupt the fragile ecosystem of the nearby Great Barrier Reef.

The situation that developed around the Carmichael mine was called "the Adani Syndrome" for the following reasons [1]:

1. For the first time, representatives of public participation defended their right to influence environmental decisions. For more than ten years, the Carmichael mine project, approved by the federal and state governments, was blocked by public participation. The project was released by the public only after making significant changes aimed at compliance with environmental requirements [8].

2. Public participation has brought about a change in Australian law. Australia experienced a complex socio-political crisis caused by the decarbonization of the economy and energy. However, as a result of the transition, the principles of public participation were incorporated into the founding laws of the Federation and the Australian National Resources De- velopment Act. Public participation has broadened the legal framework for its operations and has come to be seen as a key element in Australia's sustainable development.

The so-called "Adani Syndrome" raises a number of key issues that require careful legal analysis. The authors investigate two problems. The first problem is the criteria for assessing the environmental impact and their legal force. The second issue is the legal framework governing the rights of $(a)$ the mine owner, $(b)$ the national government and the government of the region where the mine is located, and (c) Public participation and Practitioner. The authors studied the above problems in comparison with the legal support of environmental regulation of mining in Ukraine.

The first issue raised by "the Adani Syndrome" is the criteria for assessing the impact on the environment and their legal force. All three parties to the conflict around the Carmichael mine used three different environmental impact assessments in their litigation, demonstrating three different options for "genuine" concern for the environment $[1,13]$.

The "genuineness" of the environmental impact assessment is determined by the comparative analysis between the legal framework governing the behavior of multinational corporations in developed and developing countries. Multinational corporations of any type are interested in maximizing profits and increasing shareholder value. Profit maximization is achieved primarily by reducing operating costs, including the cost of environmental protection. This is especially true for site reclamation.

The decisions of the governing bodies of developed countries are determined by environmental consciousness [14] and socio-cultural values, which specify the attitude of society to innovation, human predispositions, habits and motivation [15]. Decision making is based on an ecological approach and is aimed at protecting natural resources in the present and in the future. In this regard, the goals and objectives of the newly created (February 1, 2020) Department of Agriculture, Water and the Environment of the Australian Government are indicative [16]. "We help protect Australia's heritage and natural resources" [16].

The political crisis caused by "the Adani Syndrome" has brought environmental awareness to a new level in Australia. R. Colvin conducted an analysis of regional communities based on the traditions of social psychology to study how the social context causes the manifestation of certain characteristics of identity and norms of behavior [13]. Colvin found that regional, national and international communities clashed in the conflict over the Carmichael mine. The overwhelming majority of public organizations promoted an ecological approach and were guided by ecological awareness. A less significant part of public organizations defended the right to increase jobs in the region. As a result, even though the Carmichael mine project began, environmental awareness prevailed. The project has undergone significant changes in environmental protection [13].

An analysis of the responsibilities and legislation that govern the activities of the Department of Agriculture, Water and the Environment [16] indicates two key differences from a similar authority established in Ukraine [17]. The department has the functions of $(a)$ providing environmental information and research in this area, and $(b)$ coordinating policies for sustainable development of communities, i. e. public participation.

The socio-political crisis over the Carmichael mine project has led the Australian federal government to take on the responsibility of setting and reviewing environmental impact assessment criteria, and aligning these criteria with public participation. The course was clearly defined to coordinate Australia's sustainable development policy with the involved nongovernmental organizations. Thus, the ability of multinational corporations to influence the federal government has become limited and regulated by law. 
It is worth noting that the first National Environmental Policy Act was passed by the US Congress in 1969. The law required an environmental impact assessment for federalfunded projects that could "significantly" affect the environment [1]. The implementation of the law and the assessment process provided for by the law had important consequences not only in the United States, but also in the world. Namely, for the first time, projects, development schemes, or even a broad political vision could be delayed or even abandoned for a long time for the benefit of the environment. The law gave rise to the first law firms that represented the public interest committed to protecting the environment.

The authorities of developing countries demonstrate an opposite attitude to the environmental regulation of mining [4]. First of all, it is expressed in the absence of the clear criteria for assessing the impact on the environment and in the uncertainty of their legal force.

Uncertainty in the criteria for assessing environmental impact allows the governments in developing countries to "turn a blind eye" to shortcomings in environmental protection and to promote the projects proposed by multinational corporations. Such decisions are motivated by the desire to attract investments, create additional jobs, maintain internal political stability, or by corruption [3].

The study on the activities of the Ministry of Environmental Protection and Natural Resources of Ukraine made the authors pay attention to the following [17]:

1. The Ministry does not investigate or establish the criteria for assessing environmental impact. It suggests using "European Integration in the Sphere of Ecological Assessment", however, the proposed document deals only with recommendations and intentions [17].

2. The strategy of the Ministry, presented on the official website, does not provide for communication with the relevant public organizations [18].

Pay attention to certain shortcomings of the Law of Ukraine "On the environmental impact assessment" [19], which is designed to establish the criteria for assessing the impact on the environment. First, the provisions of the law apply not only to some types of special nature management, which makes it possible to systematically apply its procedures for all types of the specified nature management [18]. For unknown reasons, the following types of the natural resources use on the basis of permits appeared to be outside the scope of regulation:

1. Implementation of timber harvesting on an industrial scale.

2. Using pesticides and agrochemicals in the utilization of agricultural lands.

3. Economic activities that lead to the emission of pollutants into the air.

Secondly, quantitative indicators of the activities determined by the law appear to be unreasonable, provided that they are subject to the impact assessment according to a certain procedure. For example, there are no significant differences in the level of environmental risk between the operations in the field of handling household and other waste (processing, recycling, utilization, deactivation and disposal) amounting to 100 and 99.5 tons, while the former is subject to impact assessment, and the latter is not.

Thirdly, the law does not provide for legal guarantees of important aspects of the procedure established by it. Thus, there are no adequate and sufficient guarantees for the completeness and reliability of the information that is provided in the report on the planned activities, which are subject to environmental impact assessment, and in the environmental impact assessment report. The organization of the development of both of these key documents is entrusted to an a priori biased person interested in making a positive decision on the planned activities of the enterprise. The law does not provide for any legal possibilities for verifying the accuracy and completeness of the information provided, both on the part of the state authorities and on the part of the public. In accordance with the provisions of Part 3 of Article 9 of the law, verification of the information provided at the location of the control measurements of quantitative and qualitative indicators is not expected. On the contrary, the law allows only the assessment of the documents submitted by the applicant [19].

Fourthly, the law does not provide for any effective extrajudicial proceeding for appealing the decisions made as a result of the environmental impact assessment procedure. The authors believe that it is the extrajudicial proceeding in this case that is more effective than a judicial appeal. After all, there is an opportunity to organize an assessment procedure with the involvement of experts in the field of environmental management and assessment of environmental consequences of the planned activities, who will be able to independently and professionally make decisions ad rem. The court always turns to the help of experts and it is far from the fact that the current domestic forensic expert institution can conduct relevant expert studies, within which the validity of the decision made as a result of the environmental impact assessment procedure can be established. At the same time, Article 10 of the law only provides for the possibility of an authorized central or territorial governing body to form expert commissions on environmental impact assessment, whose members are appointed for a period of three years [19]. Therewith, the law does not indicate the status and powers of such commissions. In addition, not even a blanket norm on the right of the relevant authorized body to determine the powers of such commissions has been established. Thus, taking into account the provisions of Part 2 of Article 19 of the Constitution of Ukraine, we believe that it is still impossible to create the above-mentioned commissions legally.

Consider the second problem, which is actualized by "the Adani Syndrome". This is a legal framework governing the rights of $(a)$ the mine owner, $(b)$ the national government and the government of the region in which the mine is located, and (c) Public participation and Practitioner.

As we have already noted, the socio-political crisis in Australia caused by the implementation of the Carmichael mine project stimulated rethinking and clarification of the legal framework in accordance with the standards of developed countries, primarily the United States. Over the period from 2010 to 2019, there were adopted laws, on the basis of which the environmental regulation of mining was based on an ecological approach and environmental awareness [16]. This primarily affected the functions of the national government and regional governments. The Department of Agriculture, Water and the Environment is currently focused on five key areas [16]:

1. Support of stewardship and sustainable management to enhance Australia's environment and our unique heritage.

2. Management of biosecurity risks to Australian agriculture, the environment and our way of life.

3. Advance of Australia's strategic, scientific and environmental interests in the Antarctic and the Southern Ocean.

4. Support of the sustainable management and productive use of Australia's water resources.

5. Assistance to industry in growing to a $\$ 100$ billion agriculture sector by 2030 .

The Australian government is committed to the sustainable development of green technologies. The chosen strategy of the state development brings closer the interaction between the government and public participation, while reducing the influence of multinational corporations on decision making at the national level. Investors are forced to accept social, political and philosophical ideas promoted at the national level and create projects in accordance with these ideas.

The authors found a different attitude as a result of the analysis of the legal framework for environmental regulation of mining in Ukraine. A. Frantsuz analyzed modern geopolitics of Ukraine and came to disappointing conclusions [20]. Despite the course of European integration enshrined in the laws 
of Ukraine, the country is actually pursuing a policy of preserving the "old" eastern and eastern European features.

The authors compared the goals stated by the Department of Agriculture, Water and the Environment of Australia with those pursued by a similar authority in Ukraine, the Ministry of Environmental Protection and Natural Resources of Ukraine, established on May 27, 2020 [17]. The authors found the following.

First, for March 2021, the official website of the Ministry (English-language version) offers the Strategy of the National Ecological Policy of Ukraine until 2020 [17]. The Ukrainianlanguage version of the site states that "on the strategic level, the priority of environmental policy is assigned to the Draft Law of Ukraine "On the Fundamentals (Strategy) of the State Ecological Policy of Ukraine for the Period up to 2030". In fact, the Law of Ukraine "On the Fundamentals (Strategy) of the State Ecological Policy of Ukraine for the Period up to 2030" was adopted by the Verkhovna Rada on February 28, 2019 [21]. The discovered fact testifies to the low information culture of the newly created Ministry. The official website of the Ministry of Environmental Protection and Natural Resources of Ukraine does not declare the key law that determines the strategy of the state executive body.

Second, the functions of environmental regulation of mining in Ukraine are distributed among the Ministry of Energy of Ukraine, Ministry of Environmental Protection and Natural Resources of Ukraine, State Environmental Inspectorate of Ukraine, State Labor Service, State Service for Geology and Subsoil of Ukraine. This distribution introduces uncertainty in the definition of the rights of the owner, the state and public participation. The necessity of concentration of functions in one governing body and transfer to it of powers directly aimed at ensuring environmental regulation of mining in Ukraine was established.

Third, the law of Ukraine "On environmental impact assessment" attaches great importance to the procedure for assessing the impact of the public on the environment [19]. However, the law does not clearly establish the procedure for holding the relevant public discussion, which opens up the possibility of abuse during its holding. First of all, it is allowed to imitate the discussion, to hold public hearings with the involvement of the "necessary" representatives of the "public". Moreover, the law does not provide for detailed interpretation of the reasons for rejecting the public's position by the relevant authority when making decisions on environmental impact assessment. The law only provides for "examination and consideration" of the report on the results of public participation, without any detailed elaboration of what is meant and what are the grounds for taking into account (either full or partial) of the given arguments or their rejection [18, 19].

Conclusions. The study on the experience of environmental regulation of mining in Australia on the example of conflict over the Carmichael mine project allowed the authors to reveal the "true" state of Ukrainian legislation in this area. The authors came to the following conclusions.

First, currently there are no effective legal mechanisms in Ukraine to ensure environmental regulation of mining. The authors noted the ineffectiveness of the procedure for assessing the impact on the environment and exploitation. In the course of the study there was found the following:

a) ineffective distribution of powers on relevant issues between the owner, the state and the public;

b) absence of a coordination governing body and the dispersion of powers between a significant number of governing bodies lacking coordination among them;

c) an insufficient number of powers of governing bodies directly aimed at ensuring environmental regulation of mining in Ukraine;

d) dominance of economic interests over environmental ones in determining their competence.

The authors suggest the following:
First, to make changes and additions to the current legislation. In particular, the Subsoil Code of Ukraine should provide for a separate section "Ensuring the environmental safety of the mining industry". The section regulates the basic principles of the environmental safety of the mining industry (goals, means, principles).

Second, to improve the system of state executive bodies on relevant issues based on and in accordance with the basic prescriptions, with the necessary identification of one major coordination governing body and one governing body for implementation of means to ensure environmental regulation of mining, as well as to strengthen the effectiveness of control measures in this area.

Third, to improve the procedures for assessing the environmental impact when granting special permits for the use of subsoil by enhancing the ability of the public and the assessment authorities to check the actual environmental state at the site of the planned implementation of the declared activities, as well as the actual state and possible negative impact of the technologies and equipment used.

\section{References.}

1. McNamara, N., \& Crane, W. (2018). Public participation and the Adani Syndrome. Environmental and Planning Law Journal, 35(3), 320-330.

2. Vasylchenko, O. P., Lotiuk, O. S., \& Gut, N.Y. (2018). Civil society as the subject of formation of state policy in the sphere of subsoil use and protection. Naukovyi Visnyk Natsionalnoho Hirnychoho Universytetu, (6), 118-123. https://doi.org/10.29202/nvngu/2018/20.

3. Renn, O., Ulmer, F., Anna Deckert, A. (Eds.) (2020). The Role of Public Participation in Energy Transitions. Academic Press.

4. Yevstihnieiev, A. (2018). Ecological safety of special nature management in Ukraine in the context of sustainable development: theoretical and legal aspects: monograph. Kyiv: Gordon.

5. Hasan, M.A., Nahiduzzaman, K. M., \& Aldosary, A.S. (2018). Public participation in EIA: A comparative study of the projects run by government and non-governmental organizations. Environmental Impact Assessment Review, 72, 12-24. https://doi.org/10.1016/j. eiar.2018.05.001.

6. Ma, Bo (2020). Value Shaping of Ecological Man: External Standard and Internal Idea. Future Human Image, 13, 57-65. https://doi. org/10.29202/fhi/13/6.

7. International Association for Public Participation (2021). Retrieved from https://iap2usa.org/.

8. Adani mine: Australia approves controversial coal project (2019). BBC News, 13 June 2019. Retrieved from https://www.bbc.com/news/ world-australia-48618774?intlink_from_url=https://www.bbc.com/ news/world\&link location=live-reporting-story.

9. Haiko, H., Saik, P., \& Lozynskyi, V. (2019). The Philosophy of Mining: Historical Aspect and Future Prospect. Philosophy and Cosmology, 22, 76-90. https://doi.org/10.29202/phil-cosm/22/6.

10. Nalule, V.R. (2020). Social and Environmental Impacts of Mining. In: Mining and the Law in Africa. Palgrave Pivot, Cham. https:/ doi.org/10.1007/978-3-030-33008-8 3.

11. Stewart, A. G. (2020). Mining is bad for health: a voyage of discovery. Environ Geochem Health, 42, 1153-1165. https://doi.org/10.1007/ s10653-019-00367-7.

12. Bezzubov, D, \& Pravotorova, O. (2020). The Impact of Transnational Corporations on the Regulatory Framework for the World Market for Space Services and Technologies. Advanced Space Law, 6, 4-12. https://doi.org/10.29202/asl/6/1.

13. Colvin, R. (2020). Social identity in the energy transition: an analysis of the "Stop Adani Convoy" to explore social-political conflict in Australia. Energy Research \& Social Science, 66, 101492. https://doi. org/10.1016/j.erss.2020.101492.

14. Uhl, C. (2020). Developing Ecological Consciousness: Becoming Fully Human. Rowman \& Littlefield Publishers.

15. Pylypenko, H., Lytvynenko, N., \& Barna, T. (2019). Socio-Cultural Context of Innovative Development. Philosophy and Cosmology, 23, 98-111. https://doi.org/10.29202/phil-cosm/23/9.

16. Department of Agriculture, Water and the Environment (2021). Australian Government. Retrieved from https://www.awe.gov.au/about. 17. Ministry of energy and environment protection of Ukraine (2021). Retrieved from https://mepr.gov.ua/en/

18. Yevstigneyev, A. (2017). Legal providing of ecological safety of special nature use in the context of the Law of Ukraine "On Environ- 
mental Impact Assessment”. Chasopys Kyyivs'koho universytetu prava, 2, 201-204.

19. Law of Ukraine "On Environmental Impact Assessment” (2020). Revision on December 1, 2020. Retrieved from https://zakon.rada.gov. ua/laws/show/2059-19?lang=en\#Text.

20. Frantsuz, A. (2020). Central and Eastern Europe - the Globalization Process, Hybrid Threats: Political and Legal Aspects. Ukrainian Policymaker, 6, 24-31. https://doi.org/10.29202/up/6/3.

21. Law of Ukraine "About the Basic principles (strategy) of the state ecological policy of Ukraine for the period till 2030" (2019). Adoption on February 28, 2019. Retrieved from https://zakon.rada.gov.ua/laws/ show/2697-19?lang=en\#Text.

\section{Екологічне регулювання видобутку корисних копалин: правові засади}

О. П. Васильченко ${ }^{1}$, О. С. Лотюк ${ }^{1}$, А. С. Евстігнєєв ${ }^{1}$, А. В. Басалаєва ${ }^{2}$, С. М. Кустова ${ }^{3}$

1 - Київський національний університет імені Тараса Шевченка, м. Київ, Україна, e-mail: rudenkosrg@gmail.com 2 - Інститут права Національного авіаційного університету, м. Київ, Україна

3 - Юридична компанія «Катеринчук, Моор та партнери», м. Київ, Україна

Мета. Підвищити якість законодавства України шляхом удосконалення правових засад державного управління у сфері екологічного регулювання видобутку корисних копалин в Україні.

Методика. Автори використали порівняльно-правовий, історичний, системний, структурно-функціональний, формально-логічний, діалектичний методи дослідження. Автори наголошують на необхідності використання комплексного методу дослідження.
Результати. Автори дослідили дві проблеми, актуалізовані так званим «синдром Адані»:

1. Критерії оцінки впливу на навколишнє середовище та їх юридичну силу.

2. Правові засади, що регулюють права власника, держави та громадськості.

Вищезазначені проблеми були досліджені в порівнянні із правовим забезпеченням екологічного регулювання видобутку корисних копалин в Україні.

Наукова новизна. Проаналізовано досвід екологічного регулювання видобутку корисних копалин в Австралії на прикладі конфлікту навколо проекту шахти «Кармайкл» і розкрито сучасний стан законодавства України в цій галузі. Винесені на обговорення напрями вдосконалення правових засад державного управління в галузі екологічного регулювання видобутку корисних копалин в Україні.

Практична значимість. Використання отриманих результатів дозволить усунути різницю між правовим забезпеченням екологічного регулювання видобутку корисних копалин у розвинених і країнах, що розвиваються. Сформульовані пропозиції щодо вдосконалення нормативно-правового регулювання в досліджуваній сфері у частині деталізації повноважень окремих органів державної влади спеціальної компетенції, а також у частині процедур оцінки впливу на навколишнє середовище. Сформульовані пропозиції можуть сприяти посиленню ефективності чинного законодавства.

Ключові слова: участь громадськості, екологічне регулювання, видобуток корисних копалин, синдром Адані, екологічна свідомість

Recommended for publication by T. Hubanova, Doctor of Juridical Sciences. The manuscript was recommended 15.01.21. 